\title{
The Impact of IFRS Adoption on Relationship between Analyst Coverage and Earnings Management in ASEAN 5
}

\author{
Yudhistira Dharma Putra ${ }^{1}$, Aria Farah Mita ${ }^{2}$ \\ ${ }^{1,2}$ Department of Accounting, Faculty of Economics and Business, Universitas Indonesia, \\ Indonesia \\ ²aria.farahmita@ui.ac.id
}

\begin{abstract}
This research aims to give empirical evidence to prove whether the adoption of IFRS affect the relationship between analyst coverage and earnings management. This research includes 4 years period data sample on companies in ASEAN 5 countries (Singapore, Malaysia, Philippines, Indonesia and Thailand). The result shows that (1) analyst coverage can curbs earnings management behavior in both types of earnings management. This demonstrates the ability of the analyst in the external mechanisms of corporate governance. (2) IFRS adoption can curbs earnings management through above-the-line items (ALIEM), but had no significant effect on earnings management through below-the-line items (BLIEM). (3) Contrary to expectations, there is no difference in the effect of analyst coverage on both types of earnings management in the period before and after the adoption of IFRS. This may be due to financial analysts have better skills and more resources, when compared to other users in the use of the financial statements. In conclusion, without the adoption of IFRS, the analyst can use their analysis capabilities in using and understanding the financial statements.
\end{abstract}

Keywords: IFRS Adoption; Analyst Coverage; Financial Analyst; Earnings Management; Corporate Governance

\section{Introduction}

Yu (2008) reveals that there are two effects that might occur from the influence of analyst coverage on earnings management, these effects are: monitoring effect (curbing earnings management) and pressure effect (stimulate earnings management). In monitoring effect, analyst coverage is believed to have been watching the movement of the performance of the company's financial statements. This will have an impact on the management of the limited opportunities to make profits on the company's management. The previous study had much to prove this [1][2][3] In addition, analysts also published an analysis of the business prospects of companies associated with corporate earnings that could lead management to meet or exceed the analysis published by the analysts[1][2][4] This will put pressure on management and lead 
to earnings management behavior or referred to by pressure effect.

The effects arising from analyst coverage is highly dependent on the level of detection of the earnings management [5]. When an earnings management is easier to detect, the effects that tend to arise from analyst coverage is monitoring effect. Conversely, when earnings management is more difficult to detect, the effects that are likely to arise from the analyst coverage is the pressure effect.

Earnings management can be categorized into two types, namely ALIEM (Above-the-Line Items Earnings Management) and BLIEM (Below-the-Line Items Earnings Management). ALIEM is more difficult to detect because it is a reflection of the normal activities of the company's business with a number of related information are many and complex. While BLIEM easier to detect, because it is a reflection of abnormal activity of business (exceptional items) of companies with related information, which are limited and easy to find.[5] found that analyst coverage is negatively related to BLIEM proving the monitoring effect and the effect was also found that analyst coverage is positively related to ALIEM proving the pressure effect. But in other studies, particularly for ALIEM, many found that analyst coverage has a negative impact on ALIEM [1][2][3][6] The emergence of these two effects, both monitoring or pressure, which occurs as a result of the level of analyst coverage on ALIEM, shows that there are other factors that can affect the level of earnings management detectability. [5] found that the level of earnings management detectability can be influenced by the information environment within the jurisdiction of the country where the company is located and the adoption of IFRS. [5] found that the adoption of IFRS may increase the detectability of earnings management in the enterprise by improving the quality and comparability of financial statements. Increased detectability of earnings management practices lead to increased scrutiny from analysts and analysts are becoming more capable in detecting earnings management practices, so that it can be concluded that the adoption of IFRS had a negative correlation with earnings management practices. Increased detectability of earnings management due to the adoption of IFRS will have an effect on improving the detection of financial analysts on earnings management that will strengthen or weaken the effect of monitoring pressure effect. However, [5] only found a negative relationship in BLIEM, where the adoption of IFRS may strengthen the monitoring effect of analyst coverage on earnings management. Instead, it was found that the adoption of IFRS can trigger ALIEM types of earnings management practices, or in other words increases the pressure effect especially in countries with unfavorable information environment.

This study refers to the study of [5] that is related with earnings management detectability, the level of analyst coverage, and the impact of the adoption of IFRS. Adoption of IFRS which became moderating variables of analyst coverage and the level of earnings management for the first time performed by [5] After all the literature study conducted, this study is the second study on the topic. ASEAN 5 (Singapore, Malaysia, the Philippines, Indonesia and Thailand) is chosen as the research object because of market developments and prospects of high investment will lead to increased earnings management in companies in the ASEAN 5, so it is necessary to study the things that will have an impact on the earnings management. The study period is a period of 2 years before and 2 years after the adoption of IFRS in each country. This study is expected to explain the differences in the conditions before and after the adoption of IFRS.

\section{Hypothesis Development}

Agency problem occurs because of differences in the interests between the principal (shareholders) and the agent (management). Because the preparation of financial statements 
conducted entirely by the management, they may undertake certain methods in financial reporting (earnings management) in order to achieve incentive and bonuses[7][7]Analysts proven capable of performing detection against the biased behavior of management and minimize the level of agency costs in the company through its role in the external mechanism of corporate governance and engagement of private information [8] [9] Analysts' activities that continuously carried out in making an evaluation and forecast of the company, making the analysts monitoring function on earnings management becomes more effective. So that when the number of analysts increased, monitoring function will become more effective and earnings management practices will decrease. Previous research has proved this and revealed that analyst coverage had monitoring the effect on earnings management in the company[10] [2][6]

Recent studies in China found that the monitoring effect only occurs on the BLIEM type[5]. While the effects on analyst coverage on ALIEM type is pressure effect. The argument of these studies is, when a country's information environment is not good, has weak level of investor protection and lack of transparency in reporting, level of earnings management detectability will be reduced and analyst coverage will be less effective and may trigger profit management. This can happen through the analysis of earnings forecast which will add pressure to the management of the company to meet or exceed the earnings forecast issued by financial analysts and stimulate management to manage earnings in the company. All three of these conditions can increase the chances of the management to the accrual method or replacement method in applying accounting earnings management[5]Therefore, the impact of analyst coverage against ALIEM can be hypothesized two directions, both monitoring effect or pressure effect:

H1a $=$ level of analyst coverage will affect ALIEM.

Besides through ALIEM, the company can also perform earnings management through BLIEM. BLIEM is more easily detected because it is associated with abnormal activity of the company's business information is slight and limited. [5] found that the high level of analyst coverage can reduce earnings management practices through BLIEM. This is due to the high level of earnings management detectability of BLIEM types that makes it easy to detect analyst practices related to BLIEM. This conclude the second (a) hypothesis of this study:

H2a = level of analyst coverage negatively affects BLIEM.

Information asymmetry occurs as a result of the agency relationship between management and shareholders and between management and investors. IASB created IFRS with the aim to improve the quality and comparability of financial reporting among countries so the quality is better when compared to local standards. Ball (2006) revealed that the adoption of IFRS is able to improve the transparency of information and minimize information asymmetry of information on financial accounting and reporting standards of a country. This is because IFRS requires the preparers of financial statements to give disclosures of accounting information is more informative and use of fair value measurements in financial statements. [11] found that it would reduce the earnings management behavior in the management of the company. Empirical studies related to the adoption of IFRS in some countries also found that the adoption of IFRS can improve the quality of financial reporting through reduced levels of discretionary accruals[12] [13]. Based on this literature exposure, the first (b) and second (b) hypothesis of 
this study are:

H1b $=$ Adoption of IFRS negatively affect the ALIEM.

$\mathbf{H} \mathbf{2 b}=$ Adoption of IFRS negatively affect the BLIEM.

Analyst coverage not only can suppress the behavior of earnings management, but can also increase earnings management behavior. The emergence of the effect of the analyst coverage is highly dependent on the environmental conditions of information in a country[5]. When transparency is low and lead to bad environmental information, management will get the opportunity to do a profit management. Adoption of IFRS conducted by the ASEAN 5 both gradual and direct, namely Indonesia (2011), Malaysia (2005), Singapore (2003), Philippines (2005), Thailand (2014), is expected to increase transparency and improve the information environment in the country. This will increase earnings management detectability in ASEAN and the level of earnings management both on ALIEM and BLIEM can be pressed [14][15]Adoption of IFRS will further enhance the ability of analyst coverage in detecting earnings management in the company. Improving the ability of analyst coverage in detecting earnings management can be in the form of an increase or decrease pressure monitoring effect. It can be presumed that the adoption of IFRS can strengthen or weaken the effect of monitoring and pressure effect of analyst coverage on the level of earnings management both on ALIEM and BLIEM. Therefore, the third and fourth hypothesis of this study are:

H3 = Negative effect (positive) of analyst coverage on ALIEM are higher (lower) in the period after the adoption of IFRS compared with the period before the adoption of IFRS.

H4 = Adoption of IFRS reinforce negative relationship between level of analyst coverage with level of BLIEM.

\section{Research Design}

The period of this research is two years before and two years after the adoption of IFRS in each country to explain the differences in the conditions between before and after IFRS adoption. The sample used in this study are all publicly held companies with the exception of the financial industry that is consistently registered in the capital markets (excluding financial industry) at the time of the research period in each of sampled country. The research data is secondary data collected from various sources, namely Thomson Reuters DataStream and Thomson Reuters Eikon contained in the Economics and Business Data Center FEB UI. There are 2 models in this study, model 1 is used to test the hypothesis $1 \mathrm{a}$. $2 \mathrm{a}, 1 \mathrm{~b}$ and $2 \mathrm{~b}$. While model 2 is used to test hypothesis 3 and 4 . The models are shown below:

\section{Model 1}

$\mathrm{EM}_{(1,2)}=\gamma_{0}+\gamma_{1} \mathrm{ACOV}_{\mathrm{it}}+\gamma_{2} \mathrm{~PB}_{\mathrm{it}}+\gamma_{3} \mathrm{ROA}_{\mathrm{it}}+\gamma_{4} \mathrm{GWTH}_{\mathrm{it}}+\gamma_{5} \mathrm{CFVO}_{\mathrm{it}}+\gamma_{6} \mathrm{EFAC}_{\mathrm{it}}+\gamma_{7} \mathrm{MARV}_{\text {it }}$ $+\gamma_{8}$ IFRS $+\gamma_{9} \mathrm{RGDP}_{\text {it }}+\gamma_{10} \mathrm{CNTR}_{\mathrm{it}}+\varepsilon_{1}$

\section{Model 2}

$\mathrm{EM}_{(1,2)}=\delta_{0}+\delta_{1} \mathrm{ACOV}_{\mathrm{it}}+\delta_{2} \mathrm{~PB}_{\mathrm{it}}+\delta_{3} \mathrm{ROA}_{\mathrm{it}}+\delta_{4} \mathrm{GWTH}_{\mathrm{it}}+\delta_{5} \mathrm{CFVO}_{\mathrm{it}}+\delta_{6} \mathrm{EFAC}_{\mathrm{it}}+\delta_{7} \mathrm{MARV}_{\mathrm{it}}$ $+\delta_{8}$ IFRS $+\delta_{9} \mathrm{RGDP}_{\mathrm{it}}+\delta_{10}$ IFRS $^{*} \mathrm{ACOV}_{\mathrm{it}}+\delta_{11} \mathrm{CNTR}_{\mathrm{it}}+\varepsilon_{1}$

Where for company i: $\mathrm{EM}_{1}=\mathrm{ALIEM}=$ level of Above-the-Line Items Earnings 
Management (ALIEM) with discretionary accruals using the model of Dechow, et al. (1995) to test hypothesis 1a, 2a and 3; $\mathrm{EM}_{2}=\mathrm{BLIEM}=$ level of Below-the-Line Items Earnings Management (BLIEM) with Industry-median-adjusted using the model of Chen and Yuan (2004) to test hypothesis $1 \mathrm{~b}, 2 \mathrm{~b}$ and 4 ; ACOV = level of analyst coverage measured in three different ways; IFRS*ACOV = IFRS moderating variables multiplied by analyst coverage; PB $=$ price-to-book ratio $\mathrm{i}$ in year $\mathrm{t} ; \mathrm{ROA}=$ return on asset $\mathrm{i}$ in year $\mathrm{t} ; \mathrm{GWTH}=$ growth rate of firm $\mathrm{i}$ in year $\mathrm{t}$; CFVO = company's cash volatility measured by the a standard deviation of cash flow over three years and scaled by lagged assets; EFAC = funding of equity and debt scaled by total assets at year $\mathrm{t}$; MARV $=$ the natural logarithm of the market value $\mathrm{i}$ in year $\mathrm{t}$; IFRS $=$ dummy variable that is 1 for the years that have adopted IFRS, 0 for otherwise; RGDP $=$ country level of real GDP growth rate $\mathrm{i}$ in year $\mathrm{t}$; CNTR = country level dummy

ALIEM measures the value of discretionary accruals. While BLIEM measures industrymedian-adjusted BLIEM. In the model, the values of discretionary accruals (ALIEM) were calculated using Jones Model that has been modified based on research [16][17]model will be used to measure industry-median-adjusted BLIEM, i.e. the absolute value of the profit before tax reduced by income from operating activities and scaled by lagged assets. Analyst coverage is the independent variable and will be calculated with three proxies. The first measurement is variable ACOV by calculating the natural logarithm of the total analysts who follow the company in a given year plus one. The second measurement (ARES) is measured by calculating the residual value of analyst coverage model[18]. The analyst coverage model shown below:

Analyst coverage $=$ firm size + past performance + growth + external financing activities + cash flow volatilities + year dummies

Analyst Coverage is natural logarithm of the total analysts who follow the company plus one. Firm size measured by natural logarithm of company's market value, past performance is measured from the lagged ROA, growth measured by growth of total assets, external financing activities measured by the cash flow from financing activities divided by total assets, cash flow volatilities calculated by the standard deviation of cash flows companies from all over the sample period divided by lagged assets. As for the third measurement is variable ADUM that measured by treating analyst coverage to be a dummy variable. Where the value of 1 (one) will be given if the company followed by one or more analysts in a given year and the value 0 (zero) will be provided on the opposite condition.

In the fourth model of the research hypotheses, moderating variables to be tested is IFRS. This variable is a dummy variable that indicates the year of adoption of IFRS in each country. This variable is 1 for the years that have adopted IFRS are mandatory, and 0 for the year has not been the adoption of IFRS.

\section{Results}

Regression result shows that variable ACOV in model 1, has a coefficient of -0.0032 indicates that the level of analyst coverage had a negative relationship with ALIEM. Variable ACOV has a p-value of 0.019 or less than $\alpha=5 \%$, which indicates that the level of analyst coverage has a significant negative effect ALIEM. With these results, hypothesis 1a is accepted. It is proved that the effect on the level of analyst coverage on ALIEM. These results are consistent with previous studies about the negative influence the level of analyst coverage on earnings management of discretionary accruals [10][3][4] Existing literature states that high 
level of analyst coverage makes the information environment to improve and reduce the information asymmetry[8] [19]. Better capability, when compared with the shareholders and the board of commissioners as the internal mechanisms of corporate governance, making the effects of the financial analysts as a watchdog of corporate performance more effective and capable of limiting the deviant behavior of management in financial reporting. These results remained consistent at another proxy level, ARES and ADUM.

Model 1 is also used to test the hypothesis $1 \mathrm{~b}$, namely adoption of IFRS negatively affect the ALIEM. Regression result shows that the IFRS has a coefficient of -0.0055 . This shows that companies that have adopted IFRS have lower level of ALIEM, when compared to the period when company has not adopted IFRS. Variable IFRS has a p-value of 0.012 or less than $\alpha=5 \%$. This shows that the rate of adoption of IFRS have a negative influence significantly to the level of ALIEM. With these results, hypothesis $1 \mathrm{~b}$ is accepted. Lower level of ALIEM when company adopted IFRS proves that IFRS adoption negatively affect ALIEM. These results are consistent with previous studies on the negative effects of adoption of IFRS on earnings management discretionary accruals [5] [12] [13]IFRS is a principle-based standard. Extensive disclosure level in the adoption of IFRS on local accounting standards is a thing that could explain the negative impact of the adoption of IFRS to ALIEM. This led to increased level of transparency of information and increase the availability of information from the company in a country. These conditions will encourage the improvement of information environment in a country. [5] found that good information environment will improve detectability of earnings management. This earnings management becomes more detectable because adequate disclosure so that the evaluation of performance and financial companies were able to do better. In addition, the adoption of IFRS will lead to a limitation of alternative / choice of accounting methods and requires substantive economic reflection in accounting measurements. This would reduce the likelihood of earnings management practices undertaken by managers. These results remained consistent in other proxies, ARES and ADUM

Regression result shows that ACOV variable in model 2 has a coefficient of -0.0015 . This indicates that the level of analyst coverage had a negative relationship with BLIEM. Variable ACOV has a p-value of 0.055 or less than $\alpha=10 \%$. This indicates that the level of analyst coverage has a significant negative effect on BLIEM. With these results, hypothesis $2 \mathrm{a}$ cannot be rejected. This proves that the level of analyst coverage negatively affects BLIEM. These results are consistent with [5] about the negative influence of the level of analyst coverage on the real earnings management. In his research in China, [5] found that the effect of the financial analysts on BLIEM is monitoring effect. Wherein if the level of financial analysts increased, then the level of real earnings management or BLIEM will wane. BLIEM which is real earnings management, categorized as earnings management with a high level of detectability. Therefore, the analyst will easily detect their real earnings management. This simplicity will reduce the tendency of management to manage earnings in below the line item. These results remained consistent in other proxies, ARES and ADUM.

Hypothesis $1 \mathrm{~b}$ testing result also shows that IFRS can reduce ALIEM through increased transparency of information and earnings management detectability, but this does not affect the relationship between the analyst and ALIEM.[5] found the same thing on China. Financial analysts have characteristics and a better ability to use financial statements when compared to other users. In addition, analysts have privileges than other users of financial statements, which interact with the management before they issue earnings forecasts. Analysts will be given the chance to ask company executives about large coverage information that related to the company, 
such as abnormal changes in the sales and financial ratios crucial ${ }^{1}$.In addition, analysts have many channels to disseminate information about the company that has their analysis. This excess can make the adoption of IFRS can be less influential on the analysis done by analysts. [8] argue that information intermediaries such as financial analysts and rating agencies was instrumental in producing private information and can detect biased behavior management in financial reporting. It also confirms that the financial analysts can reduce management behavior such as fraud and earnings management in financial reporting. In addition, the study only covers periods of 2 years subsequent to the adoption of IFRS could also be the cause of hypothesis 3 rejection. This is because this period is not long enough to see the effect of adopting IFRS on the users of the financial statements, which in this study is the financial analyst. Hypothesis test results are consistent with other proxy measurements of analyst coverage, ARES and ADUM.

Regression result also shows that the variable IFRS*ACOV on model 4 as a variable interaction between IFRS and ACOV of research has a coefficient of -0.0003 . This shows that the adoption of IFRS reinforce the positive effects of analyst coverage against BLIEM. Variable IFRS*ACOV had a p-value of 0.425 which indicates that the adoption of IFRS are not significant in strengthening the positive effects of analyst coverage. This shows that the adoption of IFRS did not have a relationship between analyst coverage and BLIEM. With this result, hypothesis 4 is rejected. This result is consistent with the results of hypothesis $2 b$ testing where the adoption of IFRS has no effect on BLIEM. This result is in accordance to the hypothesis $2 b$ test result, that IFRS cannot increase BLIEM detectability. This is because BLIEM is an earnings management that has been easy to detect. The adoption of IFRS did not significantly increase BLIEM detectability, so it will not overly affect the process of analysis and detection of earnings management performed by financial analysts. Therefore, we can conclude that the adoption of IFRS has no effect on the relationship between analyst coverage and BLIEM.

\section{Conclusions}

This study provides empirical evidence that the IFRS adoption level does not impact the effect of the analyst coverage on earnings management. The adoption of IFRS did not significantly impact the financial analysts' behavior in monitoring a company's earnings management practices. This happens due to financial analysts' better understanding in the field of finance and the availability of information either directly or indirectly from the company compared to other users in the use of financial statements ${ }^{1}$. Thus, qualified expertise of analysts makes the adoption of IFRS becomes insignificant in helping analysts to detect the presence of earnings management in the company.

\section{References}

[1] F. Yu, “Analyst coverage and earnings management," J. financ. econ., vol. 88, pp. 245$271,2008$.

[2] F. Degeorge, Y. Ding, T. Jeanjean, and H. Stolowy, Does analyst following curb earnings management? international evidence. Working Paper, 2005.

[3] D. Knyazeva, Corporate Governance, Analyst Following, and Firm Behavior. Working Paper, 2007.

[4] F. Degeorge, J. Patel, and R. Zeckauser, "Earnings management to exceed thresholds," J. Bus., vol. 72, pp. 1-33, 1999.

[5] Y. Cang, Y. Chu, and T. W. Lin, "An exploratory study of earnings management detectability, analyst coverage and the impact of IFRS adoption: evidence from," China. J. Account. Public Policy, vol. 33, pp. 356-371, 2014. 
[6] J. Y. Sun, "Governance role of analyst coverage and investor protection," Financ. Anal. J., vol. 65, no. 6, pp. 52-64, 2009.

[7] J. Jones, "Earnings management during import relief investigations," J. Account. Res., vol. 29, no. 2, p. 228, 1991.

[8] P. Healy and K. Palepu, "Information asymmetry, corporate disclosure, and the capital markets: a review of the empirical disclosure literature," J. Account. Econ., vol. 31, pp. 405-440, 2001.

[9] M. Jensen and W. Meckling, "Theory of the firm: managerial behavior, agency costs, and ownership structure," J. financ. econ., vol. 3, pp. 305-360, 1976.

[10] Y. S. Chen, "The positive effect of green intellectual capital on competitive advantages of firms," J. Bus. Ethics, vol. 77, no. 3, pp. 271-286, 2008.

[11] C. Leuz, D. Nanda, and P. D. Wysocki, "Earnings management and investor protection: an international comparison," J. financ. econ., vol. 69, pp. 505-527, 2003.

[12] D. Zéghal, S. Chtourou, and Y. Mnif Sellami, "An analysis of the effect of mandatory adoption of IAS/IFRS on earnings management," J. Int. Accounting, Audit. Tax., vol. 20, no. 61, p. 72, 2011

[13] P. E. Dimitropoulos, D. Asteriou, D. Kousenidis, and S. Leventis, "The impact of IFRS on accounting quality: Evidence from Greece," in Advances in Accounting, incorporating Advances in International Accounting, vol. 29, no. 108, 2013, p. 123.

[14] E. Hirst and P. and Hopkins, "Comprehensive income reporting and analysts' valuation judgments," J. Account. Res. 36, vol. (Supplemen, pp. 47-75, 1998.

[15] J. E. Hunton, R. Libby, and C. L. Mazza, "Financial reporting transparency and earnings management," Account. Rev., vol. 1, no. 135- 157, 2006.

[16] P. Dechow, R. Sloan, and A. Sweeney, "Detecting earnings management," Account. Rev., vol. 70, pp. 193-226, 1995.

[17] C. W. K. Chen and H. Q. Yuan, "Earnings management and capital resource allocation: evidence from China's accounting-based regulation of rights issues," Account. Rev., vol. 79, no. 3, pp. 645-665, 2004.

[18] H.-X. Ma, X.-J. Feng, Y. Chen, C.-J. Chen, and M.-G. Zhou, "Occurrence and Characterization of Dimethachlon Insensitivity in Sclerotinia sclerotiorum in Jiangsu Province of China," Plant Dis., vol. 93, no. 1, pp. 36-42, Dec. 2008.

[19] R. Bushman, Smith, and A., "Financial Accounting Information and Corporate Governance," J. Account. Econ., vol. 32, pp. 237-334, 2001.

[20] M. E. Barth, W. R. Landsman, and M. H. Lang, "International Accounting Standards and accounting quality,” J. Account. Res., vol. 46, no. 3, pp. 467-498, 2008. 